\title{
PENGARUSUTAMAAN GENDER DALAM PENDIDIKAN PESANTREN: KAJIAN FEMINISME ISLAM
}

\author{
Masthuriyah Sa'dan \\ Indonesian Consortium for Religius Studies (ICRS) Yogyakarta, Indonesia \\ E-mail: masthuriyah.sadan@gmail.com
}

\begin{abstract}
Exit of the Beijing Platform For Action (BPFA) on gender equality mainstreaming was incorporated into development policy during the fourth world women's conference in Beijing in 1995 so Abdurrahman Wahid declared Presidential Instruction number 19 December 2000. 9 of 2000 on gender mainstreaming in national development. This is where the islamic boarding school is required to be able to respond to the dynamics of the era along with the development of modernization and globalization, so that islamic boarding school can answer the issue of gender equality discourse that goes into the boarding booths. This paper wants to answer how the strategy and implementation of Gender Mainstreaming in islamic boarding school education. This review is literature review using feminist approach and gender analysis in Islam. After the review, the authors found that the strategy for realizing gender mainstreaming in islamic boarding school education is to re-design the gender perspective teaching curriculum and the implementation of Gender Mainstreaming is through the main stakeholders of islamic boarding school namely Kyai, Nyai, Ustadzah and ustadz.
\end{abstract}

Keywords: Gender Mainstreaming; islamic boarding school education; women

Abstrak. Dikeluarkannya Beijing Platform For Action (BPFA) tentang gender mainstreaming (PUG) kesetaraan gender masuk dalam kebijakan pembangunan pada saat konferensi perempuan dunia keempat di Beijing tahun 1995 sehingga Presiden Abdurrahman Wahid pada tanggal 19 desember 2000 mengeluarkan Instruksi Presiden (Inpres) No. 9 Tahun 2000 tentang pengarusutamaan gender dalam pembangunan nasional. Disinilah pesantren dituntut untuk mampu merespon dinamika zaman seiring berkembangnya arus modernisasi dan globalisasi, sehingga pesantren mampu menjawab persoalan wacana kesetaraan gender yang masuk ke dalam bilik-bilik pesantren. Tulisan ini ingin menjawab bagaimana strategi dan implementasi PUG dalam pendidikan pesantren. Kajian ini adalah kajian pustaka dengan menggunakan pendekatan feminis dan analisa gender dalam Islam. Setelah dilakukan kajian, penulis menemukan bahwa strategi untuk mewujudkan PUG dalam pendidikan pesantren adalah melakukan re-desain kurikulum pengajaran berprespektif gender dan implementasi PUG adalah melalui pemangku utama pesantren yaitu Kyai, Nyai, Ustadzah dan ustadz.

Kata Kunci: pengarusutamaan gender; pendidikan pesantren; perempuan

Permalink/DOI: https://doi.org/10.15408/harkat.v14i2.12812 


\section{Pendahuluan}

Pemerintah Indonesia melalui Garis-garis Besar Haluan Negara (GBHN) tahun 1999 mengatakan bahwa pengarusutamaan gender merupakan kebijakan nasional yang harus diemban oleh lembaga yang mampu mewujudkan kesetaraan dan keadilan gender. Maka perlu adanya starategi yang tepat untuk melaksanakan kebijakan nasional agar menjangkau ke seluruh instansi pemerintah, swasta, masyarakat dan lain sebagainya, stategi inilah yang dikenal dengan istilah PUGpengarusutamaan gender (2005:28). Disamping itu, Undang-Undang nomor 25 tahun 2000 tentang Program Pembangunan Nasional (PROPENAS) menetapkan mengenai upaya pelaksanaan PUG yang mencakup semua bidang pembangunan, yaitu: hukum, ekonomi politik, agama, pendidikan, sosial dan budaya, pembangunan daerah, sumber daya alam, lingkungan hidup dan pertahanan keamanan (2005:33). Dengan demikian, bidang pendidikan menjadi salah satu fokus pengarusutamaan gender.

Pondok pesantren merupakan institusi keagamaan, di sisi lain sebagai basis pengembangan ilmu-ilmu keislaman klasik dan modern yang berfungsi sebagai agent of change dalam pemberdayaan dan pengembangan umat. Kontribusi pesantren dalam membina masyarakat telah diakui oleh semua kalangan, bahkan pesantren mampu menjadi motor penggerak masyarakat dalam bidang pendidikan, politik, ekonomi, sosial dan budaya. Akan tetapi, pondok pesantren "masih" tertinggal dalam merespon isu-isu gender. Hal ini disebabkan karena adanya anggapan bahwa kesetaraan gender dipahami sebagai nilai baru yang disuarakan oleh Barat bahkan dikhawatirkan dapat memporak-porandakan tradisi pesantren yang telah mapan. Berdasarkan hasil penelitian Marhumah (2009) pesantren masih cenderung mensosialisasikan ketidakadilan gender dalam pengajaran dan pendidikannya, salah satu faktor adalah karena kuatnya dominasi peran tokoh sentral pesantren (kyai dan nyai) dalam mensosialisasikan nilai-nilai dan ajaran yang masih bias gender.

Berdasarkan hasil penelitian Mastuhu (1994:277-285) bahwa pendidikan pesantren memiliki beberapa prinsip yang terdiri dari; Pertama, prinsip wisdom yaitu mencari kebijaksanaan. Prinsip ini membantu santri dalam memahami makna dan tanggung jawab hidup di tengah-tengah masyarakat. Kedua, prinsip bebas terpimpin, dalam prinsip ini anak didik bertugas belajar dan ustadznya membantu dan membimbing anak didik. Ketiga, prinsip self goverment, prinsip ini memberikan tanggung jawab pada santri untuk mengatur kehidupannya sendiri di pesantren serta mengatur bidang kegiatan di pesantren. Keempat, prinsip kolektivisme, prinsip ini dalam hal kewajiban individu harus menunaikan kewajibannya lebih dulu, sedangkan dalam hal hak individu harus mendahulukan kepentingan orang lain diatas kepentingan diri sendiri dan golongan. Dari empat prinsip yang telah dikemukakan tersebut, prinsip keadilan gender tidak ditemukan atau tidak ada dalam prinsip pendidikan pesantren. Padahal kalau di set back, keadilan gender dalam pesantren menjadi sebuah keniscayaan mengingat prinsip keadilan merupakan fondasi nilai-nilai keislaman.

Untuk memasukkan prinsip keadilan gender dalam pesantren, maka pengarusutamaan gender pendidikan pesantren menjadi niscaya karena pendidikan merupakan salah satu faktor yang memiliki peranan penting dalam meningkatkan kualitas sumber daya manusia (SDM). Gagasan Mufidah (2009:256) tentang pengarusutamaan gender di pondok pesantren Ma'had Aly Sukorejo Situbondo menjadi gagasan brilian mengingat pesantren Ma'had Aly didirikan sebagai pencetak kader ahli fiqih kontemporer (faqihus zaman). Di dalam buku 
tersebut, salah satu strategi pengarusutamaan gender yang dilakukan di pesantren Ma'had Aly adalah mendeskripsikan pemikiran santri Ma'had Aly tentang konsep gender dalam Islam, diantaranya adalah asal kejadian perempuan, hak-hak reproduksi perempuan, kepemimpinan perempuan, waris, saksi, wali dan pembagian peran gender. Hasil pemikiran tersebut kemudian dituangkan dalam bentuk implementasi berupa menerbitkan buletin "Tanwirul Afkar" dan mendirikan Pusat Studi Wanita di Institut Agama Islam Ibrahimy Situbondo.

Pengarusutamaan gender dalam pendidikan di tingkat kampus atau Ma'had Aly seperti dalam buku Mufidah diatas "mungkin" kurang sedikit mengalami kendala karena suasana, cara pandang, tingkat pendidikan dan usia santri sangat mendukung. Tapi bagaimana kalau pengarusutamaan gender tersebut diimplementasikan di pendidikan pesantren yang santrinya duduk di bangku Tsanawiyah dan Aliyah. Mengingat ada beberapa pondok pesantren tradisional, misalnya di pedalaman daerah Madura yang tidak mengadopsi sekolahsekolah keagamaan. Seperti Pondok Pesantren Tanjung Abillaits di Desa Ambunten Timur Sumenep, Pondok Pesantren Karai GulukGuluk Sumenep, Pondok Pesantren Al-Hamidy Pamekasan dan lain sebagainya. Ketiga pesantren tersebut memiliki jumlah santri mencapai jumlah ribuan yang datang dari berbagai pelosok daerah pulau Madura. Santri putra dan putri di pesantren tersebut "tidak" mengenyam pendidikan formal di tingkat Madrasah Tsanawiyah dan Madrasah Aliyah. Fokus pendidikan pesantren tersebut hanya bertumpu pada pembelajaran melalui kitab kuning yang diajarkan langsung oleh Kyai, Nyai, Ustadz dan ustadzah di pesantren tersebut. Model pesantren yang demikian bisa dilihat di beberapa daerah pedalaman tertentu di Madura dan "mungkin" di luar daerah Madura. Di pesantren yang demikian inilah, gagasan pengarusutamaan gender yang dimaksud dalam tulisan ini.

Dengan demikian, pertanyaan utama dalam tulisan ini adalah bagaimana strategi dan implementasi pengarusutamaan gender dalam pendidikan pesantren. Tujuan dari tulisan ini adalah mewujudkan pendidikan pesantren yang peka gender, humanist dan menghargai hak-hak manusia tanpa adanya perbedaan gender. Bentuk tulisan ini adalah kajian pustaka dengan pendekatan feminis dan analisa gender dalam Islam.

\section{Pendidikan Pesantren, Kitab Kuning \& Perempuan}

Santri adalah sebutan untuk seseorang yang mengikuti pendidikan ilmu agama Islam di suatu tempat, tempat tersebut bernama pondok pesantren. Secara bahasa, istilah santri berasal dari bahasa sanskerta, "shastri" yang memiliki akar kata yang sama dengan kata "sastra" yang bermakna kitab suci, agama dan pengetahuan (wikipedia.com). Sedangkan pondok pesantren adalah sebuah tempat tinggal untuk para santri yang sedang menempuh pendidikan agama Islam. Catatan sejarah Nusantara mengatakan bahwa pusat pendidikan Islam mulanya adalah langgar atau masjid, atau rumah sang guru, dimana murid duduk di lantai, menghadap sang guru dan belajar mengaji di waktu malam hari. Hal yang demikian menjadi embrio lahirnya sistem pendidikan pondok pesantren (Zuhairini, 1997). Tujuan dari pendidikan pesantren adalah membentuk manusia yang memiliki kesadaran tinggi bahwa ajaran Islam merupakan ajaran yang bersifat menyeluruh yang berhubungan dengan Tuhan, manusia dan alam. Selain itu produk pesantren ini diharapkan memiliki kemampuan tinggi untuk mengadakan responsi terhadap tantangan-tantangan dan tuntutan hidup dalam konteks ruang dan waktu yang ada (Madjid,1997:18). 
Proses pembelajaran di pesantren terdiri dari dua sistem, yakni sorogan dan bandongan. sistem sorogan bisa dilihat dimana antara kyai atau ustadz dan santri saling berhadapan (face to face). Sedangkan sistem bandongan adalah belajar bersama dimana sekelompok murid mendengarkan seorang kyai atau ustadz yang sedang membaca, menerjemahkan, menerangkan berbagai buku Islam (kitab kuning). Biasanya sistem bandongan ini disebut dengan halaqah yaitu sekelompok santri belajar di bawah bimbingan seorang guru (Dhofier, 1985). Hal yang membedakan antara pondok pesantren dengan lembaga pendidikan lainnya adalah kyai, masjid atau musholla, santri dan kitab kuning klasik. Tanpa elemen tersebut sebuah lembaga pendidikan Islam tidak dapat dikatakan sebagai lembaga pondok pesantren. Dalam hal kategori pondok pesantren, pondok pesantren memiliki dua kategori yaitu; pesantren salaf dan pesantren modern. Pesantren salaf (tradisional) mencerminkan kesederhanaan hidup bagi diri santri dan tempat tinggal santri. Sedangkan pesantren mencerminkan suatu hal yang modern dalam sistem dan bangunan fisik tempat tinggal santri.

Pada umumnya pembagian keahlian para lulusan atau alumni atau produk pendidikan pesantren berkisar pada bidang-bidang antara lain: nahwu sharaf (gramatika bahasa arab), fiqih (sekumpulan hukum amaliah), aqa'id (keyakinan), tasawuf, tafsir, hadist dan bahasa arab (Madjid,1997:07-12). Bahan ajar di pesantren tradisional di dominasi dari sumber kitab kuning. Kitab kuning menjadi rujukan utama bahan ajar guru-guru (kyai, nyai, ustadzah dan ustadz) di pondok pesantren. Sebagai sebuah lembaga pendidikan berbasis Islam, bahan ajar dan rujukan utama yang digunakan di pondok pesantren tradisional (salaf) adalah kitab kuning. Beberapa kitab kuning mengulas tentang hal-hal yang bersangkut paut dengan masalah perempuan. Dalam kajian kitab kuning di pesantren, pembahasan mengenai perempuan termasuk kategori pembahasan fiqih. Akan tetapi, pembahasan fiqih dalam kitab tersebut bersifat klasik dan karena kurang relevan dengan kondisi perempuan masa kini. Bahkan, beberapa kajian kitab kuning tersebut sangat bias gender. Lebih jelas, lihatlah tabel dibawah ini:

\begin{tabular}{|c|c|c|}
\hline No & Nama Kitab & Materi Yang Dibahas \\
\hline 01 & $\begin{array}{l}\text { Uqud al-Lujain fi } \\
\text { Bayan Huquq al- } \\
\text { Zaujain }\end{array}$ & $\begin{array}{l}\text { Pesan tentang hak } \\
\text { kewajiban suami istri } \\
\text { (pola } \\
\text { relasi antara laki-laki } \\
\text { perempuan) }\end{array}$ \\
\hline 02 & Qurrata al-'Uyun & $\begin{array}{l}\text { Adab berhubungan suami-istri, } \\
\text { seperti waktu yang } \\
\text { diperbolehkan dan tidak } \\
\text { diperbolehkan, ragam posisi } \\
\text { seks yang dibolehkan dan tidak } \\
\text { dibolehkan, serta tahapan- } \\
\text { tahapan dalam berhubungan } \\
\text { seks }\end{array}$ \\
\hline 03 & Fath al-Qorib & $\begin{array}{l}\text { Membahas tentang bersuci dari } \\
\text { hadat dan pembahasan tentang } \\
\text { nikah. }\end{array}$ \\
\hline 04 & $\begin{array}{l}\text { Fath al-Mu'in } \\
\text { Fath al-Wahab } \\
\text { Nihayat al-Zain }\end{array}$ & $\begin{array}{l}\text { Membahas tentang perkawinan, } \\
\text { bagaimana relasi suami-istri, } \\
\text { hak dan kewajiban masing- } \\
\text { masing, serta hal-hal lain yang } \\
\text { berhubungan dengan persoalan } \\
\text { itu. }\end{array}$ \\
\hline 05 & $\begin{array}{l}\text { Ihya' 'Ulum al- } \\
\text { Din }\end{array}$ & $\begin{array}{l}\text { Di pembahasan bab "Nikah", } \\
\text { disana dibahas tentang tata cara } \\
\text { berhubungan suami-istri, hak } \\
\text { dan kewajiban suami terhadap } \\
\text { istri }\end{array}$ \\
\hline 06 & $\begin{array}{l}\text { Riyadl } \\
\text { Shalihin } \\
\text { Bulugh } \\
\text { Marom }\end{array}$ & $\begin{array}{l}\text { Kedua-duanya merupakan kitab } \\
\text { hadist yang membahas antara } \\
\text { lain tentang tata cara bersuci, } \\
\text { adab buang air besar, mandi } \\
\text { janabat (mandi besar), } \\
\text { persoalan haid, masalah nikah, } \\
\text { masalah cerai (talak), ruju' } \\
\text { (kembali), nafakah dan } \\
\text { parenting (pengasuhan anak) }\end{array}$ \\
\hline 07 & $\begin{array}{l}\text { Ash-Shilah fi } \\
\text { Bayan al-Nikah }\end{array}$ & $\begin{array}{l}\text { Membahas persoalan seputar } \\
\text { perkawinan }\end{array}$ \\
\hline 08 & Adab al-Mar'ah & $\begin{array}{l}\text { Membahas seputar persoalan } \\
\text { posisi, sikap, serta hak dan } \\
\text { kewajiban perempuan terhadap } \\
\text { laki-laki. }\end{array}$ \\
\hline 09 & Tafsir Jalalain & $\begin{array}{l}\text { Membahas ayat-ayat al- } \\
\text { Qur'an yang bersangkut paut } \\
\text { dengan persoalan pernikahan, } \\
\text { hak dan kewajiban suami } \\
\text { istri. }\end{array}$ \\
\hline
\end{tabular}


Tabel I. Beberapa Kitab kuning (fiqih) yang selalu diajarkan di beberapa pondok pesantren tradisional (Subahar, 2002).

Diantara konten dan materi kitab yang disebutkan diatas mengisyaratkan keberpihakan nyata kepada laki-laki dan ketidak seimbangan hak dan kewajiban antara suami dan istri. Menurut penemuan van Bruineessen (2012:211), kitab-kitab yang diajarkan oleh pesantren, tidak terdapat nama pengarang perempuan. Akan tetapi yang ada adalah nama laki-laki. Bahkan van Bruineessen menemukan sebuah kitab karya seorang perempuan bernama Fatimah Abdul Wahab Al-Bugisi namun di halaman depan kitab tersebut tertulis nama pengarang laki-laki, yakni pamannya sendiri yang bernama Jamaluddin. Oleh karenanya, van Bruineessen menduga bahwa identitas penulis sesungguhnya dengan sengaja disembunyikan dengan anggapan bahwa menulis kitab adalah pekerjaan laki-laki. Dengan kondisi yang demikian menyebabkan teguhnya subordinasi perempuan dalam wacana pesantren.

Dengan adanya kitab klasik diatas dikarang dan ditulis oleh laki-laki dan dilestarikan di pesantren-pesantren maka pada gilirannya akan mengasumsikan sebuah pengetahuan berbasis laki-laki atas nama agama. Sehingga pengetahuan positivistik beserta teori yang dibangun merupakan konstruksi laki-laki. Oleh karenanya, Simon de Beauvoir mengatakan bahwa "dunia itu adalah hasil karya laki-laki dan perempuan merupakan jenis kelamin kedua". Disinilah kemudian Sandra Harding (1987:181) menyebut sebagai maskulinisasi epistemologi pengetahuan berbasis agama. Pengetahuan yang dimaksud disini adalah pengetahuan keagamaan Islam (dirasah Islamiyah) tentang fiqih.

Materi fiqih dalam kitab klasik tersebut sarat bias gender. Jika melihat pada sejarah (tarikhiyah) fiqih sejak dari pra kenabian Muhammad. Masyarakat Arab jahiliyah penuh dengan kekuasaan patriarkhi. Bangsa Arab memperlakukan perempuan secara tidak manusiawi. Ketika Islam datang, maka Nabi Muhammad meletakkan dasar-dasar penyamarataan keadilan yang waktu itu masih dalam kondisi zaman patriarkhi Arab. Karena sosial dan budaya bangsa Arab adalah patriakhi, maka nabi Muhammad melakukan perubahan tidak secara sekaligus, akan tetapi secara berangsur-angsur dan pelan-pelan dengan cara meletakkan beberapa hak yang dimiliki oleh perempuan. Seperti hak mendapatkan warisan, dan perlakuan yang adil kepada perempuan. Akan tetapi, para ahli fiqih pasca Nabi Muhammad, meletakkan fiqih atas dasar patriarkhi kepada masyarakat Arab yang masih bernuansa patriarkhi. Maka kemudian, jadilah perempuan sebagai barang mati, seperti kendaraan yang mewah dan perhiasan yang harus dijaga oleh penjaga dan tidak boleh keluar rumah tanpa izin suami. Jadilah kemudian pemeliharaan perempuan dan penjagaan terhadapnya berpijak pada konsep kepemilikan atas sesuatu yang berharga dan sebuah kemunafikan yang dibungkus atas nama "kehormatan" perempuan.

Ketika perempuan ingin mendapatkan hak-haknya atas nama "manusia", maka laki-laki akan mengatakan bahwa Islam telah memberikan hak-haknya kepada perempuan. AlQur'an dan hadist telah memberikan aturan dan hak preoregatif kepada perempuan yang tidak bisa dibantah, mutlak dan absolut, dan jika melanggar dari aturan tersebut maka perempuan akan mendapatkan dosa, laknat seribu malaikat, murka Allah dan akan masuk neraka dengan siksa yang amat pedih. Dengan pernyataan yang demikian, seolah-olah perempuan telah terwakili untuk mendapatkan haknya, perempuan telah terwakili untuk memikirkan sesuatu yang perempuan sendiri yang merasakan tertindas. Secara sederhana, perempuan tidak perlu memberontak dan berfikir, karena semua telah diatur dalam koridor aturan Islam yang 
bersumber dari al-Qur'an dan hadist yang terangkum dalam konsep Syari'at dan diajarkan di lembaga-lembaga pendidikan Islam (pesantren) dalam materi fiqih. Padahal kalau dikaji secara lebih intens, materi fiqih ditulis dan dikarang oleh laki-laki, untuk kepentingan lakilaki dan mengkonstruk otoritas laki-laki sehingga ayat-ayat dan hadist yang dikutip adalah ayat dan hadist yang bias gender dan misoginis. Inilah yang oleh Muhammad Shahrour (2003:399) disebut dengan tirani pemikiran. Artinya, telah ada orang yang telah memikirkan perempuan (hak, kebebasan dan kebahagiaan), karenanya perempuan tidak butuh untuk berpikir karena telah ada yang telah memikirkan perempuan. Kondisi yang demikian merupakan bentuk dari sistem pembodohan struktural.

Menurut Madjid (1997:8), fiqih merupakan sekumpulan hukum amaliah (dipraktekkan) dan disyari'atkan dalam Islam. Karena hukum amaliah tersebut dalam jangka waktu yang lama, maka kemudian fiqih mendominasi dan memegang dunia pemikiran dan intelektual Islam. Seiring dengan perkembangan agama Islam, maka terdapat keharusan adanya pembakuan sistem hukum untuk mengatur masyarakat. Pembakuan ini terjadi sekitar abad ke-2 Hijriah. Karena pengetahuan tersebut saling berkelindan dan bergumul dengan kekuasaan dinasti Islam kala itu, maka pengetahuan tentang hukum-hukum agama merupakan tangga naik yang langsung menuju pada status sosial politik yang lebih tinggi, sehingga meningkatlah orang-orang yang berminat mendalami keahlian dalam bidang fiqih. sehingga Madjid berkesimpulan, bahwa keahlian dalam fiqih merupakan konotasi terkuat dalam kepemimpinan Islam (daulah alIslamiyah). Seperti yang telah diketahui, dalam sejarah kepemimpinan Islam dari Khulafaur Rosyidin hingga dinasti Umayyah dan dinasti Abbasiyah I \& II, kepemimpinan dan kedudukan politik di dominasi oleh laki-laki.
Pertanyaanya kemudian, masih relevankah materi fiqih di ajarkan di era sekarang?. Disinilah pentingnya pengarusutamaan gender dalam pendidikan pesantren.

\section{Kebijakan Pengarusutamaan Gender Bidang Pendidikan}

Menegakkan keadilan dan kesetaraan gender merupakan prinsip-prinsip universal kehidupan manusia. Hal itu merupakan amanat Undang-Undang dasar 1945 dan komitmen nasional dalam penghapusan segala bentuk diskriminasi di Indonesia. Dalam buku Hak Azazi Perempuan (2007:8) Indonesia telah meratifikasi Convention on the Ellimination of all Forms of Diskrimination againts Women (CEDAW) melalui Undang-Undang No. 7 tahun 1984 tentang pengesahan konvensi penghapusan segala bentuk diskriminasi terhadap perempuan.

Dikeluarkannya Beijing Platform For Action (BPFA) tentang gender mainstreaming (PUG) kesetaraan gender masuk dalam kebijakan pembangunan pada saat konferensi perempuan dunia keempat di Beijing tahun 1995. Melalui kebijakan publik (governance) oleh pemerintah, swasta, organisasi sosial dan pihak-pihak lain yang terkait. Sebagai sebuah komitmen pemerintah Republik Indonesia, Presiden Abdurrahman Wahid pada tanggal 19 desember 2000 mengeluarkan Instruksi Presiden (Inpres) No. 9 Tahun 2000 tentang pengarusutamaan gender dalam pembangunan nasional, untuk mendorong, mengefektifkan, dan mengoptimalkan pelaksanaan pengarusutamaan gender secara terpadu dan koordinatif. Surat edaran tersebut disempurnakan melalui keputusan menteri dalam negeri tanggal 29 desember 2003 nomor 132 tahun 2003 tentang pedoman umum pelaksanaan pengarusutamaan gender dalam pembangunan daerah, yang kemudian dikuatkan oleh Peraturan Menteri Dalam Negeri no. 15 
tahun 2008 tentang pedoman pelaksanaan pengarusutamaan gender dalam pembangunan daerah, yang implementasinya di koordinasikan oleh Bappeda Provinsi dan Kabupaten/Kota.

Pengarusutamaan gender dalam istilah asingnya adalah gender mainstreaming. Dalam buku yang ditulis oleh Andayani dkk (2005:16), ditulis bahwa PUG adalah serangkaian strategi yang dibangun untuk mengintegrasikan gender ke dalam program pembangunan yang meliputi, perencanaan, penyusunan, pelaksanaan, pemantauan, dan evaluasi atas kebijakan dan program pembangunan. Dalam definisi yang lain, pengarusutamaan gender adalah strategi yang dilakukan secara rasional dan sistematis untuk mencapai dan mewujudkan kesetaraan dan keadilan gender dalam sejumlah aspek kehidupan manusia (baik dalam lingkup rumah tangga, masyarakat dan negara), melalui kebijakan dan program yang memperhatikan pengalaman, aspirasi, kebutuhan dan permasalahan perempuan dan laki-laki ke dalam perencanaan, pelaksanaan, pemantauan dan evaluasi dari seluruh kebijakan dan program di berbagai kehidupan dan pembangunan (wikipedia.com).

PUG memiliki tujuan jangka panjang dan tujuan jangka pendek, tujuan jangka panjang PUG adalah mempersempit dan bahkan menghapuskan segala bentuk kesenjangan gender antara laki-laki dan perempuan. Sedangkan tujuan jangka pendek PUG yang bersifat strategis adalah terselenggaranya perencanaan, penyusunan, pelaksanaan, pemantauan dan evaluasi atas kebijakan dan program pembangunan nasional yang berprespektif gender dalam rangka mewujudkan kesetaraan dan keadilan gender dalam kehidupan berkeluarga, bermasyarakat, berbangsa dan bernegara (Andayani dkk,2005:17).

Implementasi Instruksi Presiden No. 9 tahun 2000 telah melahirkan hasil antara lain: pertama, meningkatnya program pembangunan di berbagai sektor. Kedua, meningkatnya anggaran responsif gender melalui Kementerian Pemberdayaan Perempuan dan Perlindungan Anak. Ketiga, meningkatnya dukungan anggaran lintas sektoral untuk kesetaraan gender. Keempat, menguatnya kelompok-kelompok penggerak dalam koordinasi pelaksaan PUG. Kelima, lahirnya sejumlah Undang-Undang yang memberikan perlindungan pada perempuan dan anak untuk menghapus diskriminasi gender (Mufida,2009:107-108).

Dalam konteks pendidikan secara umum, PBB telah menyelenggarakan sebuah pertemuan millenium di New York pada bulan september tahun 2000. Pertemuan tersebut dihadiri oleh 189 negera anggota PBB. Mereka menyepakati Delapan Tujuan Pembangunan Millenium atau Millenium Development Goals (MDGs). Yang mana dalam salah satu hasilnya adalah merencanakan pendidikan untuk semua atau Education for All (EFA) pada Konferensi Internasional di Dakkar, yang melahirkan beberapa keputusan antara lain: pertama, memberlakukan pendidikan dasar yang universal dan memastikan bahwa anak laki-laki dan perempuan dapat menyelesaikan pendidikan dasar. Kedua, mengembangkan kesetaraan dan pemberdayaan perempuan, menghilangkan perbedaan gender di tingkat pendidikan dasar, menengah serta di semua tingkatan. Implementasi PUG dalam pendidikan nasional dikuatkan oleh Peraturan Menteri Pendidikan Nasional Nomor 84 Tahun 2008 tentang pedoman pelaksanaan pengarusutamaan gender bidang pendidikan. Regulasi ini kemudian menjadi landasan PUG bidang pendidikan, termasuk pula dalam hal ini lembaga pendidikan Islam baik negeri maupun swasta, dan pada semua satuan pendidikan mulai pendidikan anak usia dini (PAUD) hingga ke jenjang Perguruan Tinggi (Tim Penyusun,2007:01).

Meski PUG telah dirativikasi kedalam semua jenjang pendidikan dari jenjang PAUD 
hingga Perguruan Tinggi, dan dari berbagai macam pendidikan baik negeri maupun swasta, akan tetapi konsep PUG secara khusus ke dalam pendidikan jenjang pesantren yang fokus objeknya adalah santri "belum" ditemukan. Padahal pendidikan pesantren berprespektif gender atau PUG dalam pendidikan pesantren menjadi penting karena akan memberikan dan akan menjamin terpenuhinya hak pendidikan yang sama bagi perempuan dan laki-laki. Kesetaraan dan keadilan pendidikan untuk semua jenis kelamin merupakan proses transformasi pengetahuan dan nilai-nilai Islam yang berlandaskan al-Qur'an dan hadist untuk mengantarkan terbentuknya kepribadian yang mencerminkan nilai-nilai Islami dengan mempertimbangkan perbedaan kebutuhan, pengalaman, dan pengetahuan bagi perempuan dan laki-laki yang diakibatkan oleh konstruksi sosial lingkungan menuju pendidikan berkesetaraan gender agar nantinya memperoleh manfaat yang sama dari hasil pendidikan dalam mencapai tujuan yang diharapkan.

\section{Strategi \& Implementasi Pengarusutamaan Gender di Pesantren}

Dalam dinamika pendidikan pesantren, modernisasi dan globalisasi sangat mempengaruhi terhadap gerak langkah pendidikan pesantren. Sehingga wacana kesetaraan gender (gender equality discourse) menjadi bagian yang tidak terpisahkan dari kebijakan global, bahkan sudah masuk ke dalam ranah kebijakan pendidikan nasional. Di dalam kebijakan global tersebut, tertulis bahwa terdapat 10 kerangka acuan paradigma baru pendidikan nasional yang salah satunya adalah pendidikan dengan prinsip global (Jalal.eds,2001:16). Artinya pendidikan harus mampu berperan dan menyiapkan peserta didik dalam konstelasi global. Padahal wacana gender dalam lingkup pesantren "masih" banyak yang menolak (kontra) karena asumsi masyarakat bahwa pemikiran gender datang dan lahir dari Barat. Seperti yang telah diketahui, bahwa kata "Barat" selalu dikonotasikan dengan anti Islam, non muslim, dan bukan berasal dari tradisi Islam atau ajaran syariat Islam. Adanya resistensi dari beberapa pihak dari kalangan pesantren sendiri tentang pembaharuan pemikiran keislaman tentang hak-hak perempuan menjadi pemicu lahirnya dan munculnya beberapa tokoh dari kalangan pesantren juga yang mengusung lahirnya pembaharuan pemikiran keislaman di pesantren tentang hak-hak perempuan. Sehingga tokoh yang pro terhadap gender dan feminisme tersebut melakukan pengkajian ulang dan mengkritisi kurikulum pesantren yang bersumber dari kitab kuning karya ulama' klasik. Tokoh-tokoh dari pesantren yang telah melakukan pembaharuan kitab kuning dalam pesantren berprespektif gender tersebut seperti KH. Husein Muhammad, Siti Musdah Mulia, Sinta Nuriyah Wahid, Lies Marcous dan lain sebagainya. Mereka yang menerima atau pro terhadap gender dan feminisme dalam pesantren mayoritas adalah mereka yang telah berkompromi dan menerima wacana kesetaraan gender melalui proses dialog dan analisa kritis kajian akademis.

Seperti yang telah penulis singgung diatas, bahwa kebijakan pengarusutamaan gender dalam dunia pesantren belum teraplikasi dalam kurikulum dan pengajaran di pesantren. Wacana gender belum menjadi kebijakan aplikatif dalam praktek kebijakan kerukulum di pesantren. Beberapa contoh kasus kesenjangan gender dalam pesantren tersebut dapat dilihat dari kesenjangan akses, partisipasi, peran dan tanggung jawab laki-laki dan perempuan, baik pada aspek pengambil kebijakan, sistem managerial, pembelajaran, bahan ajar dan pemanfaatan fasilitas yang telah tersedia. Konsekuensinya, output santri laki-laki memiliki potensi skill yang lebih besar untuk memainkan peran publik dalam konstruk sosial ketimbang dengan santri perempuan. Kesenjangan tersebut 
juga berimplikasi terhadap kelangkaan dan minimnya intelektual muslimah atau Ulama' perempuan. Kondisi yang demikian memperburuk kondisi dan situasi perempuan di Indonesia yang terwujud dalam beberapa bentuk, seperti kesenjangan struktur sosial dalam komunitas masyarakat muslim, kurangnya peran publik perempuan dalam upaya peningkatan pemberdayaan perempuan untuk mencapai Millenium Development Goals (MDGs) dan mengatasi isu-isu gender khususnya di kalangan masyarakat muslim (Mufida,2010:20).

Seiring dengan dinamika dan PUG yang masuk ke dalam dunia pesantren, maka pesantren dituntut untuk melakukan suatu inovasi atau pembaharuan agar pesantren dapat bersentuhan dengan modernitas. Maka salah satu strategi yang dilakukan adalah dengan melakukan re-desaighn kurikulum pengajaran. Bahkan tuntutan terhadap perbaikan kurikulum ini telah berkembang menjadi wacana pembelajaran ber GSI-Gender Sosial Inclusion, yaitu pembelajaran yang mengakui dan mempertimbangkan perbedaan kebutuhan, minat, pengalaman dan cara belajar peserta didik yang disebabkan oleh konstruksi sosial pada lingkungannya (Ghafur,2008:45). Jika strategi perubahan kurikulum tersebut dilaksanakan, maka pesantren tradisional di Madura yang setia dan sangat kerasnya mempertahankan kitab kuning sebagai satu-satu media pembelajaran dan kurikul utama dalam pendidikan pesantren, maka pesantren di tuntut untuk melakukan filter ulang atau pengkajian ulang terhadap kitab kuning. Hal itu karena sumber ketidak adilan perempuan dalam tradisi pesantren bersumber pada kitab kuning oleh yang ditulis oleh ulama'ulama' klasik.

Teks-teks ayat dan hadist yang banyak dikutip oleh pengarang kitab kuning, hakikatnya teks-teks yang dikutip dalam kitab kuning tersebut merupakan konsekuensi logis dari paradigma superioritas laki-laki atas perempuan yang mendapat legitimasi dari teks-teks keagamaan lainnya. Sebagaimana dalam kajian Husein Muhammad (2004:183-184), bahwa salah satu contoh dari paradigma superioritas laki-laki atas perempuan yang mendapat legitimasi teks adalah tentang "keunggulan lakilaki atas perempuan". Adanya yang superior (laki-laki) dan yang inferior (perempuan) karena di dalam pembahasan kitab kuning yang dikarang oleh Imam Nawawi adalah, bahwa akal dan pikiran laki-laki lebih cerdas daripada akal pikiran perempuan. Pernyataan tersebut, dirujuk oleh Imam Nawawi pada QS. An-Nisa':34 "Kaum laki-laki itu adalah pemimpin bagi kaum wanita, oleh karena Allah telah melebihkan sebahagian mereka (laki-laki) atas sebahagian yang lain (wanita)" dan juga QS. AlBaqarah:228 "Dan para wanita mempunyai hak yang seimbang dengan kewajibannya menurut cara yang ma'ruf. Akan tetapi para suami, mempunyai satu tingkatan kelebihan daripada isterinya”. Disamping itu, untuk memperkokoh superioritas laki-laki, pengarang kitab kuning kemudian mengutip hadist Nabi yang mengatakan bahwa perempuan adalah "naqishat aql wa din" (kurang dalam akal dan agamanya). Dengan adanya hadist Nabi tersebut kemudian, salah satu pengarang kitab kuning yang lain yakni Ahmad bin Asymuni membangun argumentasinya dengan mengatakan bahwa "laki-laki (suami) harus mempergauli istrinya dengan baik, bersabar, melupakan perbuatanperbuatanya yang kurang baik, sebagai bentuk rasa sayang kepadanya, karena memang akalnya terbatas, sebagaimana dinyatakan dalam hadist, karena kuatnya syahwat (nafsu) perempuan, seringkali menutup akal sehat mereka, maka karena itu, mereka terbatas untuk bisa mencapai kesempurnaan".

Penjelasan dalam kitab kuning tersebut mengindikasikan bahwa perempuan adalah makluk yang inferior (lemah). Karena pandangan yang demikian itulah, maka basis materi fiqih dalam kitab kuning menganalogikan 
(mengqiyaskan) perempuan seperti barang; ketika kecil milik ayah ketika besar milik suami. Mengutip ucapan M. Amien Abdullah (Kompas,8/2/2013) bahwa kepemilikan atas tubuh perempuan yang menganalogikan perempuan seperti barang merupakan corak berpikir fiqhiyyah. Corak berpikir yang demikian sangat bertentangan dan berseberangan dengan kesadaran kemanusiaan baru (falsafiyyah) yang didukung oleh pengetahuan sosial dan humanities kontemporer tentang nonderogability (prinsip tidak dapat direndahkannya harkat kemanusiaan seseorang dengan dalih dan alasan apapun) dan human dignity-al-karamah al-Insaniyah (menjunjung tinggi harkat martabat kemanusiaan) seseorang, baik laki-laki maupun perempuan.

Meninggalkan materi fiqih dalam kitab kuning di pesantren tidaklah mudah, hal itu karena corak pendidikan pesantren selalu diidentikkan dengan kitab kuning, dan kitab kuning merupakan warisan khazanah Islam klasik. Akan tetapi, merubah diskursus kitab kuning menjadi lebih egaliter merupakan suatu keniscayaan agar sistem pendidikan di pesantren dapat bersentuhan dengan tantangan modernitas bahwa ruang lingkup kehidupan perempuan tidak hanya disekitar empat dinding rumah (domestik), bahwa persoalan perempuan dalam realitas kehidupan bukan hanya terpaku pada fiqih saja. Akan tetapi perempuan dapat berkontribusi nyata dalam menghadapi persoalan umat manusia dengan seluruh kompleksitas yang mengitarinya dan perempuan memiliki persoalan yang berhubungan dengan kesehatan, ekologi, sosial, budaya dan ekonomi. Untuk itulah diskursus keilmuan dalam Islam bukan lagi sebagai keilmuan yang tertutup, tetapi terbuka dan selalu diperlukan pengayaan dengan teoriteori sosial humaniora. Artinya, memperhadapkan permasalahan perempuan, "tidak" selalu menggunakan kajian fiqih era klasik yang tertulis dalam kitab kuning. Akan tetapi, bagaimana memperhadapkan persoalan perempuan dengan menggunakan ayat Suci sebagai legitimasi teologi dan menggunakan analisa hermeneutika dengan perspektif feminisme yang berkeadilan seperti yang telah dilakukan oleh beberapa tokoh pemikir Islam kontemporer seperti Muhammad Abduh (Mesir), Riffat Hassan (Mesir), Fatima Mernissi (Maroko), Amina Wadud Muhsin (Amerika Serikat), Nasr Hamid Abu Zayd (Mesir), Khaled Abou El-Fadl (Kuwait).

Hermenutika merupakan cara menafsirkan teks Al-Qur'an dengan konteks sosio historis masa sekarang, dan tugas pokok hermeneutika adalah bagaimana menafsirkan sebuah teks klasik dalam hal ini al-Qur'an dan hadist menjadi milik kita yang hidup di zaman dan tempat serta suasana kultural yang berbeda (Palamer,1996:17). Lebih lanjut Fazlur Rahman (1985:7-8) dua gerak ganda dalam hermeneutika. Pertama, orang harus memahami arti atau makna dari suatu pernyataan al-Qur'an dengan mengkaji situasi dan problem historis yang mana dalam al-Qur'an menjadi kunci jawabannya. Ini menyuruh untuk mengkaji situasi makro, dalam batasan-batasan masyarakat, agama, adat istiadat, lembagalembaga bahkan kehidupan secara holistik di tanah Arab ketika Islam hadir sebelum mengkaji ayat-ayat secara secara spesifik. Kedua, mengeneralisasikan jawaban-jawaban yang spesifik tersebut dan menyatakannya sebagai pernyataan-pernyataan yang memiliki tujuan moral sosial umum yang di dapat dari latar rasio historis. Artinya, ajaran-ajaran yang bersifat umum harus ditumbuhkan dalam konteks sosio historis yang kongkret pada masa sekarang, tujuannya adalah untuk mengimplementasikan nilai-nilai al-Qur'an secara baru.

Ironisnya, materi ajar dalam kitab kuning yang digunakan dalam pendidikan pesantren (salaf) tidak menggunakan analisa hermeneutika untuk tidak mengatakan anti hermeneutika. Corak paradigma pemikiran fiqhiyyah 
cenderung didominasi oleh teks. Corak yang demikian inilah yang disebut oleh Muhammad Abid Al-Jabiri (Maroko) dengan istilah dominasi epistemologi nalar bayani dalam pemikiran Islam. menurut Al-Jabiri (1991:116), nalar bayani menaruh perhatian besar dan teliti pada proses transmisi teks dari generasi ke generasi. Disini teks dijadikan sebagai sumber pengetahuan, benar tidaknya transmisi teks menentukan benar salahnya ketentuan hukum yang diambil. Artinya, jika transmisi teks bisa dipertanggung jawabkan berarti teks tersebut benar dan bisa dijadikan dasar hukum. Akan tetapi sebaliknya, jika transmisi teksnya diragukan, maka kebenaran teks tidak dipertanggungjawabkan dan tidak bisa dijadikan landasan hukum lagi.

Karena nalar bayani hanya di dominasi oleh teks, untuk itulah diperlukan adanya rekonstruksi pemikiran Islam, atau rekonstruksi paradigma pemikiran dalam pendidikan pesantren yang mulanya bercorak fiqhiyyah kitab kuning-epistemologi nalar bayani menuju corak pemikiran falsafiyyah hermeneutika feminisme. Corak pemikiran yang demikian, berupaya menafsir ulang ajaran agama (al-Qur'an, hadist, kitab kuning) agar dapat menjawab kebutuhan masyarakat modern baik laki-laki maupun perempuan.

Adapun karakteristik pemikiran falsafiyyah hermeneutika feminisme, penulis kutip dari karakteristik pemikiran keagamaan muslim progressif oleh pemikir Islam kontemporer Abdullah Saeed (2006:150-151): Pertama, mereka mengadopsi pandangan bahwa beberapa bidang hukum Islam tradisional memerlukan perubahan dan reformasi substansial dalam rangka menyesuaikan dengan kebutuhan masyarakat muslim era kini. Kedua, cenderung mendukung perlunya fresh ijtihad dan metodologi baru dalam ijtihad untuk menjawab permasalahan-permasalahan perempuan kontemporer. Ketiga, mengkombinasikan kesarjanaan Islam tradisional dengan pemikiran dan pendidikan Barat modern. Keempat, teguh berkeyakinan bahwa perubahan sosial, baik pada ranah intelektual, moral, hukum, ekonomi dan tekhnologi harus direfleksikan dalam hukum Islam. Kelima, tidak mengikutkan dirinya pada dogmatisme atau madzhab hukum dan teologi tertentu dalam pendekatan kajiannya. Keenam, meletakkan titik tekan pemikirannya pada asas keadilan sosial, keadilan gender, Hak Asasi Manusia (HAM) dan relasi yang harmonis antara muslim dan nonmuslim.

Mengenai karakteristik Islam progressif yang dijadikan karakteristik paradigma pemikiran falsafiyyah hermeneutika feminisme, penulis kutip dari penjelasan M. Amien Abdullah (2013:32) bahwa corak epistemologi keilmuan pemikiran Islam kontemporer dalam pandangan Saeed adalah berbeda dengan corak epistemologi keilmuan dan pendidikan Islam klasik-tradisional. Disini bukan agamanya yang berbeda, tetapi metode pemahaman dan pendekatannya yang berbeda dari yang pernah berlaku terdahulu. Penggunaan metode kesarjanaan dan epistemologi klasik-tradisional masih ada, dimana teks-teks (nash) al-Qur'an menjadi titik sentral, tetapi metode penafsiran dan pendekatannya telah didialogkan, dikawinkan, diintegrasikan dan diinterkoneksikan dengan mengunakan epistemologi baru yang melibatkan masukan dari natural sciences, social sciences dan humanities kontemporer.

Mengacu pada pandangan Abdullah Saeed diatas, memperhadapkan materi fiqih dalam kitab kuning di pesantren (salaf) dengan ilmu-ilmu sosial humanities kontemporer sebagai suatu keniscayaan. Dari sini, dasar hukum warisan, perkawinan, poligami, pakaian perempuan dan lain sebagainya yang telah tertulis dalam Al-Qur'an, diperjelas dengan hadist dan didokumentasikan penjelasannya oleh 
ulama' klasik dalam kitab kuning tidak serta merta diterima. Akan tetapi teks tersebut diinterpertasi dengan menggunakan analisa hermeutika dengan melihat kondisi sosiocultural ketika teks pertama kali turun, kemudian teks tersebut di interpretasi dengan menggunakan ukuran dan asas keadilan dan HAM sebagai kebutuhan pokok umat manusia kontemporer.

Menurut Husein Muhammad (2004:187-188), terdapat beberapa langkahlangkah metodologi agar teks-teks keagamaan yang selalu dikutip oleh pengarang kitab kuning agar lebih hidup, segar dan memiliki relevansi dengan ruang kontemporer tanpa kehilangan makna transendensinya. Langkah-langkah tersebut antara lain: pertama, menjadikan tujuan-tujuan syari'ah (maqashid al-syari'ah) sebagai basis utama penafsiran atau takwil. Kedua, melakukan analisis terhadap aspek sosiohistoris (al-siyaq al-tarikhi al-ijtima'ie) atas kasus-kasus yang ada dalam teks. Ketiga, melakukan analisis bahasa dan konteksnya (alsiyaq al-lisani). Keempat, melakukan identifikasi aspek kausalitas dalam teks sebagai jalan ke pemikiran analogis untuk kebutuhan konteks sosial sekarang (qiyas al-ghaib 'ala al-syahid). Kelima, melakukan analisis kritis terhadap sumber-sumber transmisi hadist (takhrij alasanid) dan kritik matan (naqd al-matan).

\section{Mewujudkan PUG di pesantren} tradisional yang "hanya" berkutat pada pengajaran kitab kuning bukanlah hal yang mudah. Hal itu karena akan mendobrak akan merubah paradigma dan orientasi pesantren dari kungkungan jeratan pemikiran ulama' klasik yang sudah "ketinggalan" zaman. Karenanya, implementasi PUG di pesantren tradisional harus dimulai dari adanya kesadaran penuh bahwa perempuan dalam lembaran kitab kuning terdiskriminasi, streotipe dan termarginalkan. Tanpa adanya kesadaran, maka implementasi PUG hanya tinggal wacana.
Seperti yang telah diketahui, bahwa fokus sentral atau pemegang utama kendali pesantren terletak di tangan seorang kyai. Kyai di pondok pesantren merupakan salah satu elemen yang sangat esensial. Kyai merupakan tokoh panutan yang sangat di hormati santri. Sebagai tokoh panutan dan figur sentral, maka segala tindak laku kyai selalu diperhatikan oleh santri. Karenanya, metode pengajaran dan perubahan kurikulum pesantren untuk mengimplementasikan PUG di dalam pendidikan pesantren, di kyailah kuncinya. Sayangnya, sepembacaan penulis selama menjadi santri dan alumni pesantren tradisional di Madura, persoalan gender masih bias di pesantren. Bias gender yang kental tersebut termanifestasi dalam bentuk pengajaran pesantren yang masih "setia" menggunakan kitab kuning yang bias gender, juga pengajaran yang disampaikan atau metode pengajaran tidak luput dari streotipe penafsiran-penafsiran yang bias gender yang menomorduakan perempuan. Padahal kyai sebagai kunci utama atau pengendali tercapainya PUG dalam pesantren.

\section{Penutup}

Harus diakui konsep dan gagasan PUG seperti yang telah penulis paparkan diatas, memang untuk ranah pendidikan sekolah dan Perguruan Tinggi. Tapi tidak menutup kemungkinan pesantren-pesantren tradisional juga menerapkan konsep PUG yang demikian. Tidak mudah mengingat konsep PUG memulai dari perubahan bentuk kurikulum, perubahan metode pengajaran hingga materi yang diajarkan. Apalagi guru-guru di pesantren tradisional di Madura khususnya kyai dan nyai yang sudah sepuh "biasanya" belum sampai ke jenjang "kesadaran" gender. Hal itu karena biasanya, orang-orang pesantren tradisonal menganggap bahwa hukum fiqih yang ada dan kitab kuning yang telah diajarkan tidak perlu adanya perubahan. Taklid yang tinggi tersebut 
merupakan kendala besar terwujudnya gagasan dan implementasi PUG di pesantren. Tapi kita tidak boleh menyerah dengan keadaan, sesuatu bisa berubah kalau kita mau merubahnya dari sekarang.

Ada beberapa strategi yang bisa digunakan untuk membumikan gagasan pengarusutamaan gender di pesantren tradisional. antara lain: Pertama, menjadikan kitab kuning klasik sebagai "warisan" intelektual ulama' masa dahulu dan bukan sebagai dasar pengambil keputusan (dogmatisme hukum) jika berbenturan dengan kondisi masa kini, sehingga materi pengajaran pesantren tidak hanya berfokus kepada kitab kuning saja tapi juga menggunakan literatur karya ulama' kontemporer yang kajian keagamaanya bersentuhan dengan hak asasi manusia (human dignity). Kedua, pemerhati perempuan terutama dalam bidang pendidikan mengadakan advokasi kebijakan kurikulum pesantren kepada pemangku otoritas pesantren yaitu kyai. Ketiga, mengadakan pelatihan atau workshop tentang penyadaran gender dan konsep pengarusutamaan gender kepada guru-guru di pesantren terutama kepada Kyai, Nyai, ustadz, dan ustadzah. Keempat, mengingatkan atau memberi saran kepada para kyai-kyai untuk selalu menekankan konsep kesetaraan (al-musawa), keadilan (al'adilah) dan hak asasi perempuan (al-harakah alinsaniyah) dalam lingkungan pesantren ketika kegiatan bahtsul matsail. Kelima, pemerintah dalam hal ini kemenag menyediakan layanan pelatihan PUG dalam pendidikan pesantren untuk para pemangku pesantren seperti kepada kyai, nyai, ustadzah dan ustadz. Disamping itu, Kemenag juga mengembangkan materi pembelajaran pesantren berprespektif gender.

\section{Daftar Pustaka}

Abdullah, M. Amien. 2013, Agama, Ilmu dan Budaya; Paradigma Integrasi-Interkoneksi Keilmuan, pidato pengukuhan keagggotaan
Akademi Ilmu Pengetahuan Indonesia (AIPI), Yogyakarta 17 Agustus 2013.

Abdullah, M. Amin. 2013. Agama \& Perempuan, Kompas Edisi Rabu, 06 Februari 2013.

Andayani, dkk. 2005. Pengarusutamaan Gender Universitas Islam Negeri Sunan Kalijaga Yogyakarta, Yogyakarta:PSW UIN SUKA.

Bruinessen, Martin Van. 2012. Kitab Kuning, Pesantren \& Tarekat, Terj. Farid Wajidi \& Rika Iffati, Yogyakarta: Gading Publishing.

Dhofier, Zamakhsyari. 1985. Tradisi Pesantren: Studi Tentang Pandangan Hidup Kyai, LP3ES, Jakarta.

Ghafur, Waryono Abdul. 2008. GSI Dalam Perspektif Pendidikan Islam, Yogyakarta: Makalah UIN SUKA.

Harding, Sandra. $1987 . \quad$ Conclusion: Epistemological Question, Feminist and Methodology; Social Science Issue, Bloomington and Indianapolis:Indiana University Press, 1987.

https://id.wikipedia.org/wiki/Pengarusutamaan gender

Jalal, Fasli \& Supriadi, Dedi. (eds.). 2001. Reformasi Pendidikan Dalam Konteks Otonomi Daerah, Yogyakarta: Adicita.

Madjid, Nurcholish. 1997. Bilik-Bilik Pesantren: Sebuah Potret Perjalanan, Jakarta: Paramadina.

Marhumah. 2009. Gender Dalam Lingkungan Sosial Pesantren: Studi Tentang Peran Kyai dan Nyai Dalam Sosialisasi Gender di Pesantren Al-Munawir dan Pesantren Ali Maksum Krapyak Yogyakarta, Disertasi tidak diterbitkan.

Mastuhu. 1994. Dinamika Sistem Pendidikan Pesantren, Jakarta: INIS.

Mu'in, Abdul dkk. 2006. Survey Tipologi Pondok Pesantren Dalam Pemenuhan Pelayanan Pendidikan Keagamaan Bagi Masyarakat. dalam http://www.depag.web.id diakses hari selasa, $12 / 4 / 2016$ pukul 14.36 
Mufida CH. 2009. Bingkai Sosial Gender: Islam, Strukturasi dan Konstruksi Sosial, Malang: UIN Maliki Press.

Mufidah. 2009. Gender di Pesantren Salaf, Why Not?. Menelusuri Jejak Konstruksi Sosial Pengarusutamaan Gender di Kalangan Elit Santri, Malang:UIN-Maliki Press.

Muhammad 'Abid Al-Jabiri. 1991. Bunyah al'Aql Al-'Arabi, Beirut:al-Markaz al-Tsaqafi al-'Arabi.

Muhammad, Husein. 2004. Islam Agama Ramah Perempuan: Pembelaan Kyai Pesantren, Yogyakarta:LkiS.

Rahman, Fazlur. 1985. Islam dan Modernitas Tentang Transformasi Intelektual, Bandung: Pustaka.

Richard E. Palamer. 1996. "Hermeneutic" dikutip dari Komaruddin Hidayat, Memahami Bahasa Agama Sebuah Kajian Hermeneutika, Jakarta: Yayasan Paramadina.
Saeed, Abdullah. 2006. Islamic Thought: An Introduction, London and New York:Routledge.

Shahrour, Muhammad. 2003. Tirani Islam, Geneologi Masyarakat dan Negara, Terj. Saifuddin Zuhri Qudsi \& Badrus Syamsul Fata, Yogyakarta: LkiS.

Subahar, Abd Halim, 2002, Pesantren Gender: Konstruksi Baru Basis Pemberdayaan Perempuan, dalam Jurnal Al-Adalah STAIN Jember Vo. 5 No.2.

Tim Penyusun. 2007. Hak Azazi Perempuan: Instrumen Hukum Untuk Mewujudkan Keadilan, Jakarta: Yayasan Obor Indonesia.

Tim Penyusun. 2007. Panduan Pengarusutamaan Gender Bidang Pendidikan: Buku II Kebijakan Pengarusutamaan Gender Bidang Pendidikan, Malang: Indonesia Australia Partnership in Basic Education.

Zuhairini. 1997. Sejarah Pendidikan Islam, Bumi Aksara: Jakarta. 